\title{
PERBANDINGAN KADAR ENZIM KREATININ FOSFOKINASE DAN NYERI OTOT SEBELUM DAN SESUDAH LATIHAN BERENANG SELAMA EMPAT MINGGU PADA PERENANG UNIT KEGIATAN MAHASISWA KLUB RENANG
}

\author{
Nur Akmal binti A'ffan', Reni Farenia ${ }^{2}$, Delita Prihatni ${ }^{3}$ \\ ${ }^{1}$ Fakultas Kedokteran, Universitas Padjadjaran, Bandung, Indonesia \\ ${ }^{2}$ Divisi Fisilogi, Fakultas Kedokteran, Universitas Padjadjaran, Bandung, Indonesia \\ ${ }^{3}$ Departemen Patologi Klinis, RSUP Dr. Hasan Sadikin, Bandung, Indonesia
}

\begin{abstract}
A research has been done to compare the differences on the enzyme creatine phosphokinase (CPK) level and muscle soreness before and after 4-weeks swim practices on swimmers of College swimming club. Eighteen healthy male swimmers (mean $\pm S D$; age: 19,94 \pm 1,86 years; weight: 65,28 $\pm 6,14 \mathrm{~kg}$; height: 1,72 \pm 0,43 $m)$ participated in this study. All subjects performed their 4-weeks swim practices which consist of $2 x 120$ hours per week with 500 meters average daily swim distance and weight training. Blood was collected before and after the practices and CPK were analyzed. Questionnaires concerning muscle soreness were filled put before each blood draw. Results were analyzed using normality test and Wilcoxon signed rank test $(p<0.05)$. There was significant increase in CPK level during 4-weeks swim practices by $59.41 \%(p=0.044)$. Whereas for muscle soreness (overall and specifically in arms and thighs), there was no significant differences between before and after the 4-weeks swim practices. As a conclusion, participation in 4-weeks swim practices resulted in significant serum CPK enzyme elevation, but there was lack of significance in muscle soreness differences on swimmers of College swimming club.
\end{abstract}

Keywords: creatine phosphokinase, muscle soreness, swim

Korespondensi: Redaksi JIFO, Laboratorium Sentral, Universitas Padjadjaran, Jalan Raya Jatinangor KM. 21, Sumedang, Jawa Barat, Indonesia. E-mail: amrosdianto@gmail.com 


\section{INTRODUCTION}

The swimming performance in Indonesia has been well masked by past successful achievement by its athlete especially in SEA Games level. However, there are decrements in athlete's performance lately om SEA Games competition. ${ }^{1}$

In sports, performance results depend on maintaining an optimal balance between training and recovery. The athletes' response to underperformance is often an increase in training rather than rest, and this serves to further exaggerate the recovery deficit. Therefore, this will cause a condition known as overtraining which describe as excessive frequency, volume, or intensity of training, resulting in fatigue. One of the symptoms of overtraining is excessive muscle injury. ${ }^{2,3}$

Sport injury could occur especially to muscles, ligaments, skins, bones, and other tissues. ${ }^{4}$ muscular damage resulting from vigorous exercise is a common and normal event. Athletes often feel muscular soreness between 8 and 24 hours postexercise, with peak levels occurring at around 48 hours..$^{5}$ this soreness is called delayedonset muscle soreness (DOMS) and is thought to be the result of the muscular damage that can occur with any type of high intensity workout and has been reported to occur at the level of the sarcolemma, $\mathrm{Z}$ discs, or both. ${ }^{6,7}$ Although it is normal to sustain muscular damage with exercise, excessive damage can cause a condition known as exertional rhabdomyolysis. Exertional rhabdomyolysis is the degeneration of skeletal muscle caused by excessive unaccustomed exercise and has been known to cause death in healthy athletes. ${ }^{6,7}$

There are many enzymes used to assess muscular damage such as creatine phosphokinase (CPK), lactate dehydrogenase (LDH), adolase, and transaminase. CPK enzyme is the preferred screening tool because unlike other enzymes found in skeletal muscle, CPK has relatively predominance in skeletal muscle and is not falsely elevated by hemolysis. It also being unbound in cell cytoplasm and is readily released in cellular injury. ${ }^{8}$ Assessing CPK level has been commonplace for more than 3 decades in studies investigating muscular damage. ${ }^{9}$

Increase in blood levels of CPK are one indicator of muscular trauma. Normal resting levels of CPK for men are 55 to $170 \mathrm{U} / \mathrm{L}$ and for women are 30 to $35 \mathrm{IU} / \mathrm{L} .{ }^{10}$ the reference for $\mathrm{CPK}$ in male and female athletes was twice those for male and female non-athletes. The references CPK intervals were 82 $1083 \mathrm{U} / \mathrm{L}$ in male athletes and 47-513 $\mathrm{U} / \mathrm{L}$ in female athletes. Therefore, comparing the CPK level of athletes to the normal level established on nonathletes is pointless. ${ }^{11}$

The level of CPK depends on type of muscle contractions. Eccentric contractions are known to cause more muscle injury than concentric contractions, resulting in higher increases of $\mathrm{CPK}^{11}$ As swimming produce concentric contraction of the upper and lower limb muscles, causing minor muscle damage and only small increases in CPK. Hence, the CPK level in swimmers are around 70-523 U/L. ${ }^{11}$

Although studies of muscular damage and CPK are somewhat common, most have been conducted in the controlled environment. Few studies have been done on athletes participating in their daily training activity. ${ }^{12,13}$ This research was done to compare $\mathrm{CPK}$ level and muscle soreness before and after 4-weeks swim practices on swimmers of College swimming club as an indicator for muscle damage. 


\section{METHODS}

This is an analytical study with comparison. Twenty male swimmers of College swimming club were volunteered from a pool of athletes that remained on swimming club for that month. New members did not participate because they lack swimming technique. Two subjects were dropped from the study as loss to follow up and musculoskeletal injuries, leaving 18 subjects to complete the research protocol. The study was approved by Health Research Ethics Committee Faculty of Medicine Universitas Padjadjaran. The inclusion criteria were those in good health condition based on questionnaire, no history of cardiovascular disease, free from heavy physical exercise that can cause fatigue and exhaustion at least 2 days before the study, and an active swimmer. The exclusion criteria were those suffer from musculoskeletal injuries.

Subjects will perform swimming practices for 4 weeks period. A swim training of the subjects for 4 weeks duration is obtained by questionnaire. $^{14,15}$ Around 3-4 mL of blood were drawn on the evening which was before the start of swimming practices and CPK analysis was

\section{RESULT}

The description of subject's physical characteristics includes age, body weight, body height, and body mass index (BMI). It is presented in table 1. All subjects were involved in a swimming and weight training program directed by their coach. The intensity of their training is shown in table 2.

Wilcoxon signed rank test is used to know the significant difference on the CPK enzyme level before and after 4weeks swim practices on swimmers of College swimming club. The result is presented in table 3. The mean CPK level before swimming is $255 \pm 177.9$ and the mean CPK level after 4-weeks performed by the laboratory at local hospital. The laboratory used the cobas c311 analyzer. The value range less than 190 U/L was considered normal using this procedure. $^{10}$ Muscle soreness is tested twice before and after 4 weeks swimming practices using Likert scale questionnaire. Subjects were asked to gently palpate and move various muscle groups through a comfortable range of motion then rate their soreness using standard scale $0-4$.

Data analysis is processed using SPSS v.15.0 program for Windows with statistical significance testing $\mathrm{p}<0.05$. Normality test using Saphiro-Wilk test. ${ }^{16}$ A non-parametric test is used to compare two dependent samples with ordinal data or with numerical observations that are not normally distributed. ${ }^{16}$ When data is normally distributed, dependent t-test $(p<0.05)$ is used to compare two dependent samples. ${ }^{16,17}$

The study was conducted at swimming pool of UPI, Bandung, starting from February - April 2011. The places used to measure CPK enzyme level are at Hasan Sadikin Laboratory and Lab. Trio Diagnostika.

swim practices is $406.5 \pm 402.9$. Therefore, the changes of CPK level are increasing as many as $59.41 \%$. The rest result shows that the average changes of CPK level before and after 4-weeks swim practices is significant $(\mathrm{p}<0.05)$.

Description about changes in muscle soreness before and after swimming is presented in figure 1. It shows that most of subjects responded to 0 (no soreness) rating for overall muscles soreness before and after group. There were fifteen and eleven subjects responded to 0 (no soreness) rating in before and after group, respectively. Hence, the changes are 
found to decrease by as much as $26.67 \%$

on overall muscles soreness.

Table 1. Physical characteristics of subjects.

\begin{tabular}{lcccccc}
\hline Characteristic & N & Min & Max & x & & SD \\
\hline Age (years) & 18 & 18 & 25 & 19.94 & \pm & 1.86 \\
Height (m) & 18 & 1.64 & 1.8 & 1.72 & \pm & 0.43 \\
Weight (kg) & 18 & 57 & 75 & 65.28 & \pm & 6.14 \\
BMI & 18 & 19 & 24.7 & 21.92 & \pm & 1.54 \\
\hline
\end{tabular}

$\mathrm{X}=$ Average

$\mathrm{SD}=$ Standard deviation

$\mathrm{BMI}=$ Body mass index

Table 2. Intensity of training.

\begin{tabular}{lc}
\hline & $\begin{array}{c}\text { Training period } \\
\text { (4 weeks) }\end{array}$ \\
\hline Number of swimming workouts per week & 2 times \\
Duration of swimming workouts (in minutes) & 120 \\
Average daily distance (meter) & 500 \\
Average number of weight training workouts per week & 1 time \\
\hline
\end{tabular}

Table 3. Wilcoxon signed rank test for CPK level before and after 4-weeks swim practices on swimmers of College swimming club.

\begin{tabular}{|c|c|c|c|c|c|c|c|c|c|}
\hline Variable & Group & $\mathbf{X}$ & SD & Ranks & $\mathbf{N}$ & $\begin{array}{l}\text { Mean } \\
\text { Rank }\end{array}$ & $\begin{array}{l}\text { Sum of } \\
\text { Ranks }\end{array}$ & $\mathbf{Z}$ & Sig. \\
\hline \multirow[t]{2}{*}{$\begin{array}{l}\text { CPK } \\
\text { level }\end{array}$} & Pre & 255 & 177.887 & $\begin{array}{l}\text { Negative } \\
\text { ranks } \\
\text { Positive } \\
\text { ranks }\end{array}$ & 12 & $\begin{array}{c}6.8 \\
9.92\end{array}$ & $\begin{array}{c}34 \\
119\end{array}$ & \multirow[t]{2}{*}{$-2.012 *$} & \multirow[t]{2}{*}{0.044} \\
\hline & Post & 406.5 & 402.902 & $\begin{array}{l}\text { Ties } \\
\text { Total }\end{array}$ & $\begin{array}{c}1 \\
18\end{array}$ & & & & \\
\hline
\end{tabular}

* Significant at $\alpha=5 \%$

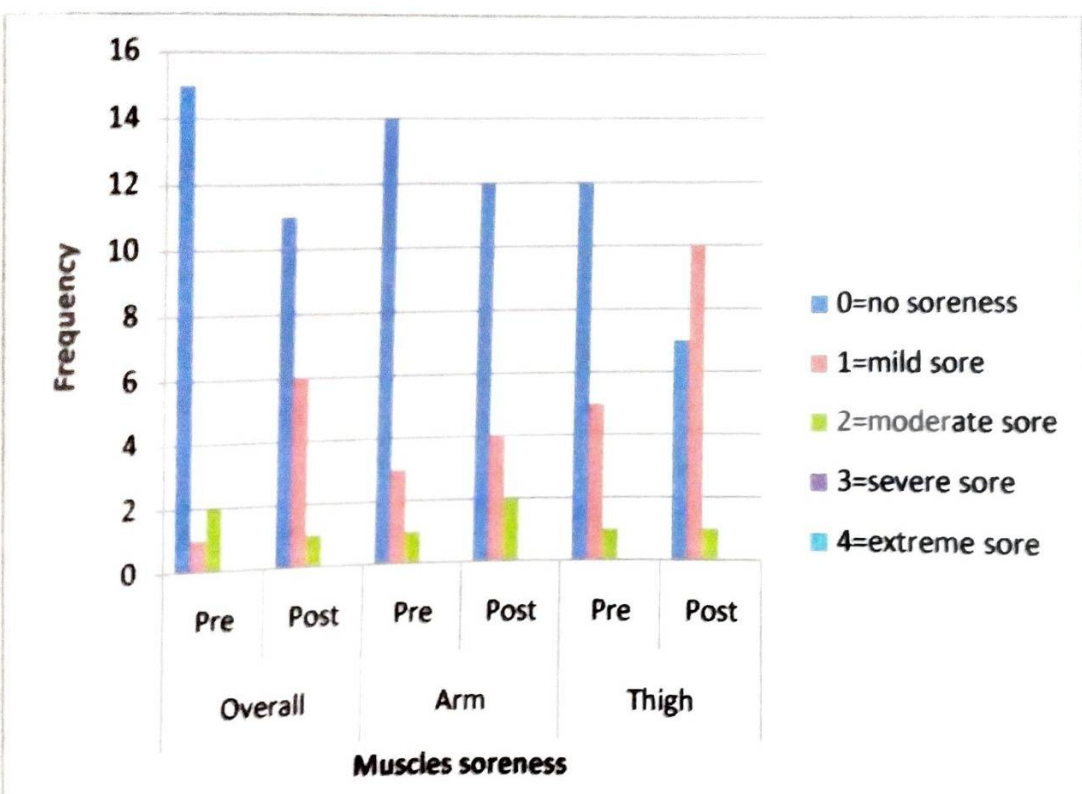

Figure 1. Muscle Soreness Rating (Overall and Specifically in Arms and Thighs) Before and After 4-Weeks Swim Practices on Swimmers of College swimming club. 
Table 4. Wilcoxon signed rank test for muscle soreness before and after 4-weeks swim practices on swimmers of College swimming club.

\begin{tabular}{|c|c|c|c|c|c|c|c|c|c|}
\hline Variable & Group & Min & Max & Ranks & $\mathbf{N}$ & $\begin{array}{l}\text { Mean } \\
\text { Rank } \\
\end{array}$ & $\begin{array}{l}\text { Sum of } \\
\text { Ranks }\end{array}$ & $\mathbf{Z}$ & Sig. \\
\hline \multirow{4}{*}{$\begin{array}{c}\text { Overall } \\
\text { soreness }\end{array}$} & \multirow{2}{*}{ Pre } & \multirow{2}{*}{0} & \multirow{2}{*}{2} & $\begin{array}{l}\text { Negative } \\
\text { ranks }\end{array}$ & 2 & 6 & 12 & \multirow{4}{*}{-0.905} & \multirow{4}{*}{0.366} \\
\hline & & & & $\begin{array}{l}\text { Positive } \\
\text { ranks }\end{array}$ & 6 & 4 & 24 & & \\
\hline & \multirow{2}{*}{ Post } & \multirow{2}{*}{0} & \multirow{2}{*}{2} & Ties & 10 & & & & \\
\hline & & & & Total & 18 & & & & \\
\hline \multirow{3}{*}{$\begin{array}{c}\text { Arm } \\
\text { soreness }\end{array}$} & \multirow{2}{*}{ Pre } & \multirow{2}{*}{0} & \multirow{2}{*}{2} & $\begin{array}{l}\text { Negative } \\
\text { ranks }\end{array}$ & 3 & 5.5 & 16.5 & \multirow{3}{*}{0.749} & \multirow{3}{*}{0.454} \\
\hline & & & & $\begin{array}{l}\text { Positive } \\
\text { ranks }\end{array}$ & 6 & 4.75 & 28.5 & & \\
\hline & Post & 0 & 2 & $\begin{array}{l}\text { Ties } \\
\text { Total }\end{array}$ & $\begin{array}{c}9 \\
18\end{array}$ & & & & \\
\hline \multirow{3}{*}{$\begin{array}{c}\text { Thigh } \\
\text { soreness }\end{array}$} & \multirow[b]{2}{*}{ Pre } & \multirow[b]{2}{*}{0} & \multirow[b]{2}{*}{2} & $\begin{array}{l}\text { Negative } \\
\text { ranks }\end{array}$ & 2 & 5 & 10 & \multirow{3}{*}{-1.667} & \multirow{3}{*}{0.096} \\
\hline & & & & $\begin{array}{l}\text { Positive } \\
\text { ranks }\end{array}$ & 7 & 5 & 35 & & \\
\hline & Post & 0 & 2 & $\begin{array}{l}\text { Ties } \\
\text { Total }\end{array}$ & $\begin{array}{c}9 \\
18\end{array}$ & & & & \\
\hline
\end{tabular}

For arms muscle soreness, it shows that most of the subjects responded 0 (no soreness) rating for both before and after group. There were fourteen and twelve subjects responded to 0 (no soreness) rating in before and after group respectively. Hence, the changes are found to decrease by as much as $14.29 \%$ on arm muscle soreness rating.

For thigh soreness, most of the subjects responded to 0 (no soreness) rating in before group while in after group, most of the subjects responded to 1 (mild sore) rating. There are twelve and seven subjects responded to 0 (no soreness) scale in before and after group, respectively. The changes are found to decrease by as much as

\section{DISCUSSION}

A description of normal four weeks practices is important in understanding the findings. Generally, the swimmers warmed up with approximately 10 minutes of static stretching and form running. Then, they will perform swimming practices directed by their coach. Average swimming distance in one day is around
41.67\%. Apart from that, there are five and ten subjects responded to 1 (mild sore) scale in before and after group, respectively. The changes are found to increase by as many as $50 \%$ on thigh soreness rating.

To determine significance of the result, Wilcoxon signed rank test is used and the result is shown in table 4. It shows that all variables have minimum muscle soreness rating of 0 (no soreness) scale and maximum rating of 2 (moderate sore) scale. The test result shows that there is no significant changed in muscle soreness (overall and specifically in the arms and thighs) before and after 4-weeks swim practice ( $p>0.05)$.

500 meters. The swimming practices were done twice a week with each session last for 2 hours. In addition, they also performed weight training workout once a week as their dry land training.

There has been considerable controversy in the literature concerning the magnitude of changes in serum CPK following exercise. This is a result pf 
several confounding variables such as subjects in varied states of training, time lapse between blood sampling and cessation of exercise, relative intensity of exercise, and duration of the exercise. $^{14}$

Examination of pre CPK level shows that even though the subjects has not begun their practices yet, the mean CPK level was $255 \pm 177.9$, which is higher than the published CPK norms for healthy men. Norms for CPK level are 55-170 U/L. A study showed that it is common for healthy exercising athletes to have blood CPK level ranging from 100-1000 U/L. These high resting CPK level were attributes to decreased enzyme removal from the blood, permanently damaged muscle cell membranes as a result of chronic physical stress, higher lean body mass of athletes, higher level of protein breakdown, or a combination of all these factors. If the muscle damage that occurs is one-time event, normal clearance of CPK level from the blood can generally be expected in 2-3 days with peak levels occur around 18 hours after injury. ${ }^{10,18}$

A statistically significant rise in CPK was noted from condition pre exercise compared to post exercise $(\mathrm{p}<0.05)$. However, not all swimmers in this study were taken blood sample 5 minutes after exercise. This is due to there is only one registered lab analyzer. Hence, the subjects need to take turn to take their blood samples. This is categorized under the limitation of study. Because of this reason, the actions can be taken in the future to overcome it.

Beside that, the difference in CPK results also is due to measurement bias in this research. The reason to this is due to time difficulty, a different laboratory needs to be used to evaluate CPK level of some subjects. Semi-automatic analyzer was used instead of automatic analyzer that was used in Hasan Sadikin
Hospital. The procedure to measure CPK is similar but different method was used.

A previous study was conducted to measure CPK levels in football players undergoing 2-a-day practices. The result showed the CPK level after practices was $5124.7 \pm 5518.1 \mathrm{U} / \mathrm{L}$. This post exercise CPK level of football players were higher than the CPK level of swimmers in this study because football training involves great deal of the leg muscles, such as during landing after a jump. Eccentric contractions are known to cause more muscle injury than concentric (shortening) contractions, resulting in higher increases of serum CPK. In addition, football playing can induce muscle damage due to mechanical impact with other players. $^{10,11}$

In this study, the increase in muscle soreness before and after swimming is not significant. The possible explanation for this is that the swimmers might have been adapted to their swim training. As a result, the muscles become resistant to damage from subsequent exercise. ${ }^{19}$

It seems more likely that the type of exercise - intensity, duration or type of contraction - influences muscle soreness. Most researchers have started from the observation that soreness is most severe after eccentric contractions, since swimming involved concentric contraction of upper and lower limb muscles, hence it causes minor muscle soreness. ${ }^{11}$

Besides that, an elevation in CPK level in swimmers of College swimming clubsuggested that they may impose insufficient degrees of trauma producing muscular stress. This is normal physiologic process happen in subject who exercise. However, CPK level increase 5 to 10 times higher than normal resting state will lead to severe muscle damage known as exertional rhabdomyolysis. These signs followed 
by vital symptoms such as extreme muscle pain and presence of myoglobin in urine which manifested by dark cola color urine. ${ }^{7,10,18}$

As with any study performed in this field, internal validity is sacrificed for external validity, as illustrated by several limitations present in this study.

\section{CONCLUSION}

The conclusion for this study is there is significant increase in CPK level in swimmers of College swimming club, before and after 4- weeks swim practices and there are no significant

\section{FUNDING}

This research was not funded by any grant sources.

\section{CONFLICT OF INTEREST}

There was no conflict of interest.
One limitation is the small number of subjects, which limits extrapolation of the result. Other limitations include temperature and humidity variation from practice to practice and day to day, fitness and hydration status of the participants, as well as nutritional status. $^{10}$

changes in muscle soreness rating 9overall and specifically arms and thighs) on swimmer of College swimming club, before and after 4weeks swim practices.

\section{REFERENCES}

1. Purwandono RA. Pembinaan prestasi olahraga renang melalui perkumpulan renang. Jurnal Olahraga Prestasi. 2006

2. Sharp N, Marterson G. Monitoring your athletes vs overtraining. Coach and Athlete Director. 2007

3. Peterson A. Overtraining. Exercise Physiology Educational Resources. 2000.

4. Nieman DC. Fitness and sport medicine: An introduction. Edisi pertama. California: Bull Publishing Company; 1990.

5. Rosene J, Mathews T, Ryan C, Belmore K, Bergsten A, Blasdell J, et al. Short and longer term offects of creatine supplementation on exercise induced muscle damage. Journal of Sports Science and Medicine. 2009;8;89 -96.

6. Eichner ER. Exertional rhabdomyolysis. Curr Sports Med Rep. 2008;7(1);3-4.

7. Caban G, Martin L, Scavone F. Exercise-induced rhabdomyolysis.

J Am Podiatr Med Assoc. 2007;97(3);234-7.

8. Gasper CM, Gilchrist MJ. Creatine kinase: A review of its use in the diagnosis of muscle damage. 2005.

9. Dawson DM, Fine IH. Creatine kinase in human tissues. Arch Neurol. 1967;16(2):175-80.

10. Ehlers GG, Ball TE, Liston L. Creatine kinase levels are elevated during 2-A-day practices in collegiate football players. J Athl Train. 2002;37(2):151-6.

11. Mougios V. Reference intervals for serum creatine kinase in athletes. Br J Sports Med. 2007;41(10):6748.

12. Young A. Plasma creatine kinase after the marathon: A diagnostic dilemma. $\mathrm{Br}$ J Sports Med. 1984;18(4):269-72.

13. Siegel AJ, Silverman LM, Lopez RE. Creatine kinase elevations in marathon runners: Relationship to training and competition. Yale J Biol Med. 1980; 53(4):275-9. 
14. Millard M, Zauner C, Cade R, Reese R. Serum CPK levels in male and female world class swimmers during a season pf training. Journal Swimming Research. 1985.

15. Hoffman JR, Yarom Y, Zigel L, Einbinder M. Hormonal and biochemical changes in elite basketball players during 4-weeks training camp. Strength and Conditioning Research. 1999:2805.
16. Dawson B, Trapp RG. Basic \& clinical biostatistics. Edisi ke-4: McGraw Hill; 2004.

17. Norman GR, Streiner DL. Biostatistics: The bare essentials. Edisi ke-3: People's Medical Publishing House; 2008.

18. Brancaccio P, Maffulli N, limongelli FM. Creatine kinase monitoring in sport medicine. $\mathrm{Br}$ Med Bull. 2007;81-82:209-30.

19. Tiidus PM. Skeletal muscle damage and repair. Edisi pertama. America: Human Kinetics Publishers; 2008. 